\title{
A Systematic Literature Review of Liquidity, Asset Quality, Efficiency, and Solvability of Profitability on Foreign Bank
}

\author{
Arie Dwi Kurniawati \\ Department of Management, STIE Perbanas Surabaya, Surabaya \\ e-mail: ariedwikurniawati17@gmail.com
}

\begin{abstract}
An assessment of the performance of a foreign bank can be done by analyzing its financial statements. Financial performance of foreign banks in Indonesia when viewed from ROA has not been satisfactory. The aim of this study is to analyze whether the LDR, NPL, BOPO, and CAR have significant influence simultaneously and partially to ROA foreign banks. The paper is conceptual and qualitative in nature. This study examines 8 previous studies that discussed the effect of liquidity, asset quality, efficiency and solvability of profitability in banks. The Study followed a descriptive research design and used secondary data obtained from the company annual reports and partly from the foreign bank. There are one basic theory about signaling theory and previous research found some propositions : 1) LDR have significant effect to ROA, 2) NPL have significant effect to ROA, 3) BOPO have significant effect to ROA, 4) CAR have significant effect to ROA. The implication of this research can be used as input for banks in managing business risk in an effort to obtain the expected level of profit.
\end{abstract}

Keywords—Liquidity, Asset Quality, Efficiency, Solvability.

\section{INTRODUCTION}

$\mathrm{T}$ HE banking sector of a country has enormous influence. Complex effects and impacts on other industrial sectors cause the risks faced are even greater for a country's economy. Banking has always evolved to meet people's need. That is why bankig products and services continue to grow as the grow. This has become a demand for banks because the public wants bank products and services that can facilitate their needs and service quickly and efficiently. The most important banking activity is to buy money by assembling public funds [1].

Based on RI Law Number 10 of 1998, a bank is a business entity that collects funds from the public in the form of deposits and distributes them to the public in the form of credit and or other forms in order to improve the lives of many people. Replacing the money market, which is a process that conforms to the international economic openness of countries. The more globalizing the financial markets makes it easier and the greater the volume of interstate economic activity; otherwise, the more liberal world economic system accelerates the process of financial globalization because of the greater funding needs for production and investment activities.

According to Rivai, Globalization has positive and negative impacts [1]. The positive effects of globalization such as an increase in national income because it has a comparative advantage, access to global capital, the spread of technology, the spread of human rights and increased employment opportunities so as to improve the welfare of a country's society. On this basis, international trade organizations and many economists argue that globalization is driving economic growth and reducing poverty and income inequality. While the negative impact of globalization is the weakening of the position of countries lacking skills and capital, weak management in international trade by poor countries, exploitation of workers in poor countries, the risk of unstable global capital markets, weakening of national cultural stability, national economic autonomy is undermined by capital market openness, and poorer countries must accept policies made by richer countries.

Of course, the presence of foreign banks has advantages compared to local or domestic banks. One thing that can be seen is to have technological innovations and risk management that is far better and wider access in the financial markets. The central bank still carries the interest of the lower interest and the lower interest on the lower interest rate and the lower interest on the lower interest rate. There are 10 foreign Banks that can be seen on Table 1 .

Table 1 shows that the profitability of foreign banks through the ROA ratio during the 2015-2019 period tended to increase, as indicated by an average trend of 0.34 . But apparently there are still many foreign banks that during the period profitability tends to decline. This suggests that there is still a problem on foreign Banks' profitability. Theoritically, the factors that affect profitability in a bank can be seen through bank performance, namely liquidity, asset quality, efficiency, and solvency. Profitability can be seen in the extent of effectiveness that the banking operations have achieved. The company will be good if it makes a high profit, which can be measured by an adjudicator which will be the profitability ratio.

\section{THEORITICAL REVIEW}

Financial Performance. According Al-Homaidi, financial performance is an effort to obtain results through the company's operations which consist of various activities by helping leaders improve the effectiveness of employee work and of course by providing appropriate rewards [2].

Solvability. According to Al-Homaidi this ratio is used to determine the company's ability to pay off its entire debt which is guaranteed by the amount of the company's assets [2].

Capital Adequancy Ratio (CAR). CAR is the ratio of bank performance to measure the capital adequacy of banks 
The $1^{\text {st }}$ International Conference on Business and Engineering Management (IConBEM)

February $1^{\text {st }} 2020$, Institut Teknologi Sepuluh Nopember, Surabaya, Indonesia

Table 1.

Profitability On Foreign Bank Period December 2015 - September 2019 (In Percent)

\begin{tabular}{|c|c|c|c|c|c|c|c|c|c|c|c|}
\hline \multirow{2}{*}{ No } & \multirow{2}{*}{ Banks Name } & \multicolumn{9}{|c|}{ Year } & \multirow{2}{*}{ Mean Tren } \\
\hline & & 2015 & 2016 & Tren & 2017 & Tren & 2018 & Tren & 2019 & Tren & \\
\hline 1 & American Express Bank Ltd. & 3.23 & 3.33 & 0.1 & 1.56 & -1.77 & 3.66 & 2.1 & 3.37 & -0.29 & 0.035 \\
\hline 2 & Bank of America, N.A & 0.51 & 1.37 & 0.86 & 2.05 & 0.68 & 2.11 & 0.06 & 2.24 & 0.13 & 0.4325 \\
\hline 3 & Bank of China (Hongkong) Limited & 1.35 & 2.88 & 1.53 & 2.62 & -0.26 & 3.16 & 0.54 & 3.23 & 0.07 & 0.47 \\
\hline 4 & Citibank NA & 2.77 & 4.47 & 1.7 & 4.65 & 0.18 & 3.02 & -1.63 & 4.82 & 1.8 & 0.5125 \\
\hline 5 & Deutche Bank AG. & 3.24 & 3.83 & 0.59 & 3.89 & 0.06 & 3.5 & -0.39 & 4.43 & 0.93 & 0.2975 \\
\hline 6 & JP.Morgan Chase Bank, N.A. & 1.41 & 2.5 & 1.09 & 0.87 & -1.63 & 0.57 & -0.3 & 1.74 & 1.17 & 0.0825 \\
\hline 7 & MUFG Bank, Ltd & 2.31 & 2.82 & 0.51 & 2.66 & -0.16 & 3.29 & 0.63 & 4.07 & 0.78 & 0.44 \\
\hline 8 & Standard Chartered Bank & -0.55 & 0.58 & 1.13 & 0.32 & -0.26 & 1.26 & 0.94 & 0.83 & -0.43 & 0.345 \\
\hline 9 & The Bangkok Bank Comp. LTD & 2.51 & 1.62 & -0.89 & 2.67 & 1.05 & 2.29 & 3.81 & 1.13 & -1.16 & 0.7025 \\
\hline 10 & The Royal Bank of Scotland N.V & -0.21 & -0.38 & -0.17 & -0.11 & 0.27 & 0.26 & 0.37 & 0.23 & -0.03 & 0.11 \\
\hline & Mean Trend & 1.66 & 2.30 & 0.65 & 2.12 & -0.18 & 2.31 & 0.61 & 2.61 & 0.30 & 0.34 \\
\hline
\end{tabular}

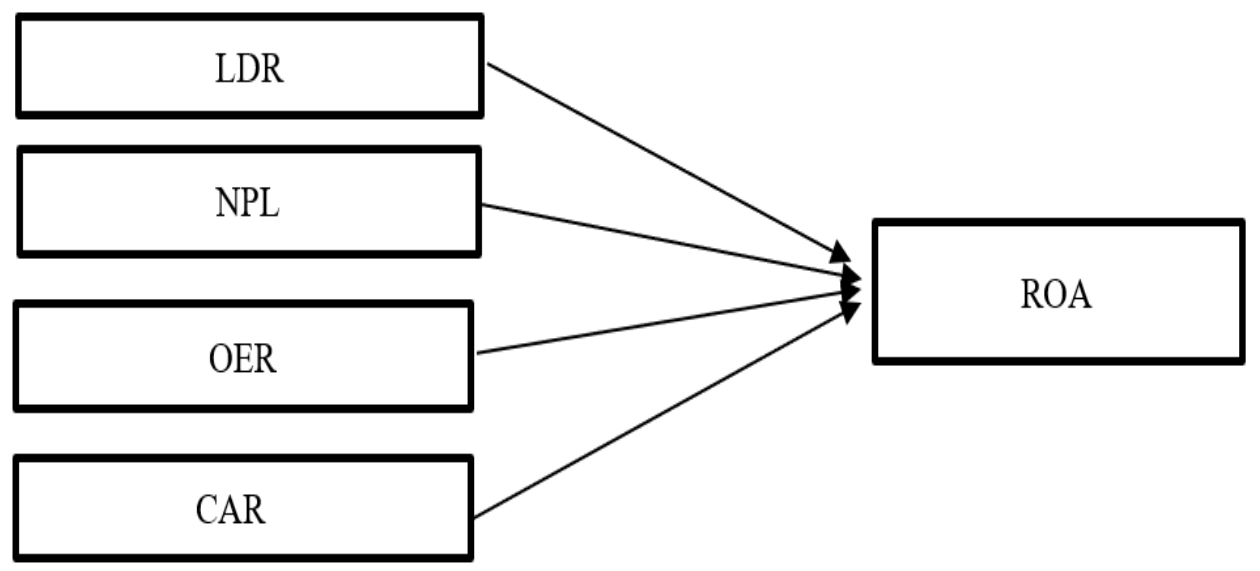

Notes :

LDR : Loan to Deposit Ratio

NPL : Non-Performing Loan

OER : Operating Efficiency Ratio

Figure 1. Framework

CAR : Capital Adequacy Ratio

to support assets that contain or generate risk, for example loans and the risks that will occur in trading securities. CAR can be calculated by using this following formula:

$\mathrm{CAR}=\frac{\text { Equity Capital }- \text { Fixed Assets }}{\text { Total Loans }+ \text { Securities }}$

Quality Asset. Asset Quality is all total assets owned by banks with the intention to obtain the expected income.

Non Performing Loan (NPL). NPL is one of the key indicators to assess the performance of bank functions, because high NPL is an indicator of banks failing in managing business, including liquidity problems (inability to pay third parties), profitability (debt cannot be billed), and solvency (reduced capital). NPL can be calculated by using this following formula:

$N P L=\frac{\text { non performing loans }}{\text { total loans }} \times 100 \%$

Liquidity. Liquidity is a measure of ability and ease an asset that can convert into cash. Liquid assets are those who can be converted into cash quickly if needed to meet a financial obligation; Liquid assets generally include cash, central bank reserves, and government debt. To remain viable, financial institutions must have sufficient liquid assets to meet their short-term obligations, such as withdrawals by depositors [3].

Liquidity to Deposit Ratio (LDR). According to Harahap, the LDR is a ratio used to measure the composition of the amount of credit given compared to the amount of public funds and own capital used [3]. LDR can be calculated by using this following formula:

$\mathrm{LDR}=\frac{\text { total loans }}{\text { total deposit to equity }} \times 100 \%$

Efficiency. Efficiency itself is the ability of companies to manage resources that are properly owned without waste.

Operating Efficiency Ratio (OER). OER is the ratio between operating costs to operating income. Operating costs are costs incurred by the bank in carrying out its main business activities (such as interest costs, labor costs, marketing costs and other operating costs). Operating income is the main income of the bank, namely interest income derived from the placement of funds in the form of loans and other operating income. OER can be calculated by using this following formula:

$\mathrm{BOPO}=\frac{\text { operational cost }}{\text { operational income }}$

Profitability. Harahap explains that profitability is the company's ability to earn profits in relation to sales, total assets, and own capital [3].

Return on Asset. According to Rivai ROA is a ratio used to measure banks' overall profitability [1]. Profit obtained from earning before tax obtained by a bank is the net profit derived from operational activities which makes pre-tax returns. Total asset is the average volume of business or assets 
The $1^{\text {st }}$ International Conference on Business and Engineering Management (IConBEM)

February $1^{\text {st }} 2020$, Institut Teknologi Sepuluh Nopember, Surabaya, Indonesia

over the past twelve months. ROA can be calculated by using this following formula:

Return on investment $/$ Asset $=\frac{\text { earning before tax }}{\text { Total asset }} \times 100 \%$

\section{METHOD}

This research is a conceptual and qualitative research. This study examines 8 previous studies that discussed the effect of liquidity, asset quality, size, and efficiency on bank profitability.

\section{DISCUSSION}

From the explanation of the foundation of banking theory that will be examined and the results of previous studies that are used as a reference that has been obtained the results of a research framework on the effects of independent variables which in this study used four variables including LDR, NPL, BOPO, and CAR which can be seen more clearly in Figure 2 about the framework that will be used in the research conducted this time.

The effect of asset quality on bank profitability is supported by previous research conducted by Abdillah; Salike and Ao; Chiquita et al.; Alshatti, who obtained results that asset quality has significant negative impact on bank profitability [4]-[7]. The effect of efficiency on banking profitability is supported by previous research conducted by Yahya et al.; Alshatti; Chiquita et al.; Lemiyana and Litriani, which have the effect of efficient results. significant negative effect on profitability [6]-[9]. The effect of Solvability on bank profitability is supported by previous research conducted by Nohong; Yahya et al.; Salike and Ao, which obtained the result that solvability have a positive significant effect to profitability [5], [8], [10]. The effect of liquidity on bank profitability is supported by previous research conducted by Nohong and Chiquita which obtained the result that solvability have a positive significant effect to profitability [6], [10].

Based on the background, methods, framework of thought and discussion, the hypotheses proposed are:

H1: Liquidity has a significant effect to profitability.

$\mathrm{H} 2$ : Asset quality has a significant negative effect to profitability.

H3: Efficiency has a significant effect to profitability.

H4: Solvability has a significant negative effect to profitability

\section{RESULT}

\section{A. The Effect of Liquidity to Profitabilit}

LDR has a positive impact on ROA. LDR improves the increase, then indicates an increase in the amount of credit given by banks by a greater percentage than the percentage increase in third party funds, as a result an increase in interest income that is greater than an increase in interest costs, increases bank income increases and ROA of a bank will increase. The influence of LDR on ROA has proven that Alshatti and Chiquita et al. with LDR research results showed a positive effect on profitability [6], [7].

\section{B. The Effect of Asset Quality to Profitability}

NPL has a negative impact on ROA. This can happen if the NPL increases, an increase in non-performing loans with a percentage level greater than the percentage increase in total credit, as a result an increase in fees reserved is greater than the increase in income, so that bank profits decline and ROA of a bank will also decrease. The influence of NPL on ROA has been proven by Chiquita et al. and Alshatti with NPL research results negatively affecting profitability [6], [7].

\section{The Effect of Efficiency to Profitability}

BOPO has a negative impact on ROA. This can happen if the BOPO increases, an increase in operational costs is greater than the increase in bank operating income, this causes the costs incurred by the bank is greater than the income received by the bank, resulting in decreased bank profits and ROA of a bank also decreases.

The effect of BOPO on ROA has been proven by Yahya et al. and Alshatti which results in BOPO having a negative effect on profitability [7], [8]. Research conducted by Chiquita et al. and Lemiyana produced a BOPO that had a significant negative effect on profitability [6], [9].

\section{The Effect of Solvability to Profitability}

CAR has a positive influence on ROA. A bank that has sufficient capital translates into higher profitability. the higher CAR achieved by the bank shows the bank's performance is getting better so company profits are increasing. In the results of this study a positive CAR which means that CAR has a positive and significant effect on ROA. The effect of CAR on ROA has been proven by Yahya et al. with the results of LDR research having a positive effect on profitability [8]. Research conducted by Nohong and Harahap produce LDR significantly influence profitability [3], [10].

\section{CONCLUSION}

From the discussion above, it can be seen how important profitability is to the financial performance of banks. the globalization of the financial market which the process took place simultaneously with the economic openness of the countries in the world (the implementation of the world free trade system). The increasingly globalized financial markets make it easier and greater the volume of economic activity between countries; conversely the more liberal world economic system accelerates the process of financial globalization because of the greater funding needs for production and investment activities.

\section{REFERENCES}

[1] V. Rivai, S. Basir, S. Sudarto, and A. P. Veithzal, Commercial Bank Management Manajemen Perbankan. Jakarta, Indonesia: Raja Grafindo Persada, 2013.

[2] E. A. Al-Homaidi, M. I. Tabash, N. H. S. Farhan, F. A. Almaqtari, and D. McMillan, "Bank-specific and macro-economic determinants of profitability of Indian commercial banks: A pane data approach," Cogent Econ. Financ., vol. 6, no. 1, pp. 1-6, 2018 , doi: 10.1080/23322039.2018.1548072.

[3] S. S. Harahap, Analisis Kritis atas Laporan Keuangan. Jakarta, Indonesia: Raja Grafindo Persada, 2015

[4] R. Addillah, M. N. Hosen, and S. Muhari, "The determinants factor of islamic bank's profitability and liquidity in Indonesia," Knowl. Horizons - Econ., vol. 8, no. 2, pp. 140-147, 2016.

[5] N. Salike and B. Ao, "Determinants of bank's profitability: role of 
The $1^{\text {st }}$ International Conference on Business and Engineering Management (IConBEM)

February $1^{\text {st }} 2020$, Institut Teknologi Sepuluh Nopember, Surabaya, Indonesia

poor asset quality in Asia," China Financ. Rev. Int., vol. 8, no. 2, pp. 216-231, 2018, doi: 10.1108/CFRI-10-2016-0118.

[6] J. C. Sumanti and M. Mangantar, "Analisis kepemilikan manajerial, kebijakan hutang profitabilitas terhadap kebijakan dividen dan nilai perusahaan pada perusahaan manufaktur yang terdaftar di BEI," J. EMBA J. Ris. Ekon. Manajemen, Bisnis dan Akunt., vol. 3, no. 1, pp. 1141-1151, 2015, doi: 10.35794/EMBA.V3I1.7928.

[7] A. Sulieman Alshatti, "Determinants of banks' profitability - the case of Jordan," Invest. Manag. Financ. Innov., vol. 13, no. 1, pp. 84-91, 2016, doi: 10.21511/imfi.13(1).2016.08.

[8] A. T. Yahya, A. Akhtar, and M. I. Tabash, "The impact of political instability, macroeconomic and bank-specific factors on the profitability of Islamic banks: an empirical evidence," Invest. Manag. Financ. Innov., vol. 14, no. 4, pp. 30-39, 2017, doi: 10.21511/imfi.14(4).2017.04.

[9] L. Lemiyana and E. Litriani, "Pengarih NPF, FDR, BOPO terhadap Return On Asset (ROA) pada Bank Umum Syariah," IECONOMICS A Res. J. Islam. Econ., vol. 2, no. 1, pp. 31-49, 2016.

[10] M. Nohong, "Strategic environment and bank performance; (Empirical study of bank listed in Indonesian stock exchange period 2011-2015)," J. Econ. Bus. Account. Ventur., vol. 19, no. 3, pp. 325-334, 2017, doi: 10.14414/jebav.v19i3.767. 